\section{Construction and Use of an Inexpensive in Vitro Ultrasonic Misting System}

\author{
Brent Tisserat, Daniel Jones, \\ and Paul D. Galletta
}

Additional index words. aeroponics, asexual embryogenesis, carrot, plant tissue culture, humidifier

Summary. An inexpensive user-constructed ultrasonic misting system to grow plant tissues in vitro is presented. This system is constructed by coupling two commercially available products, a culture chamber and an ultrasonic humidifier. Plant cultures are grown within a culture chamber on a platform and bathed periodically by an ultrasonic nutrient mist. Carrot cultures were found to grow as much as four to 10 times as great as those grown on agar medium.

W ithin the past few years, a number of novel plant tissue culture items and systems have become available commercially, such as the Falcon CultuSAK (Becton Dickinson Labware, Lincoln Park, N.J.), De Novo automated micropropagation system (De Novo, San Dimas, Calif. ), Vegbox plant containers (Plant Production Systems B.V., Helmond, The Netherlands), and the Mistifier (Manostat, New York, N.Y.). These novel systems improve culture growth rates and/or decrease labor for reculturing activities. One of the most interesting newly developed products has been a sterile aeroponics culture system (Fox, 1988; Weathers and Giles, 1988 ). Nutrients and water are supplied to the cultures in a fine mist that completely bathes the culture. The Mistifier is composed of a number of modular components: An ultrasonic mist generator module, an air pump, a culture chamber, a misting controller

Agricultural Research Service, U.S. Department of Agriculture, Fruit and Vegetable Chemistry Laboratory, Pasadena, CA 91106. unit, and a peristaltic pump. Unfortunately, this aeroponics unit is expensive, retailing for about $\$ 4000$ each. The cost of this unit precludes any indepth testing with the aeroponics system for the average plant tissue culture researcher. As an alternative, we report on the construction of a considerably less-expensive ultrasonic misting system (UMS). Comparison of growth responses obtained from misting carrot cultures with other tissue culture systems are given herein.

\section{Construction of the ultrasonic misting system}

A list of items to construct the UMS is given in Table 1. A Sunbeam 1.2-gal ultrasonic humidifier (Model \#66004; Sunbeam Appliance Co., Milwaukee, Wis.), obtained from a local drug store, provided the ultrasonic misting element and power supply. The humidifier was modified by removing the units ultrasonic misting element and connecting the units liquid level sensor (LLS) so that it is permanently closed. The humidifier AC cord was connected to an Intermatic Time-All Timer (Intermatic Inc., Spring Grove, Ill.) equipped with $24 \mathrm{on} /$ off settings per day (Fig. 1A). The culture chamber was constructed of polycarbonate $(180 \mathrm{~mm}$ height $\times$ $340 \mathrm{~mm}$ length $\times 170 \mathrm{~mm}$ width) and was equipped with three air-vent filters (Fig. $1 \mathrm{~A}$ and B). The chamber was modified by mounting a polypropylene LLS and the ultrasonic misting element at the bottom end of the chamber. The LLS was mounted in a 1/8-27 NPT tapped hole. The ultrasonic misting element was mounted underneath a 19.05-mm-diameter hole. Nylon bolts, washers, and nuts and Buns-N O-rings were employed to secure the misting element to the chamber for a liquid-tight fit via two additional 2.2-mm-diameter holes. The culture chamber was attached to the medium reservoir with $60 \mathrm{~cm}$ of silicone tubing, $2.5 \mathrm{~mm}$ id. $\mathrm{x} 4.5 \mathrm{~mm}$ o.d. (Fig. 1A). The level of the medium in the growth chamber was kept at a constant $25 \mathrm{~mm}$ depth by connecting the LLS to the medium reservoir via the unidirectional peristaltic pump (Fig. 1A).

Cultures were incubated on a polypropylene culture tray consisting of a rectangular perforated polypropylene sheet $(300 \mathrm{~mm}$ length $\times 130 \mathrm{~mm}$ wide $\mathrm{x} 5 \mathrm{~mm}$ thickness with $4.75-\mathrm{mm}$ diameter holes staggered on $7.94-\mathrm{mm}$ centers) mounted on four corner-positioned 45-mm-long x 15-mm-diameter Deb-in rods (Fig. 1 B ). Polypropylene netting (63 x 75 strands/cm) was placed on the surface of the tray to provide support for tissues. It is important that the misting element s bubbling pathway be free of obstructions to obtain the best misting performance; therefore, an opening was made in the

Table. 1. List of materials required for construction of the ultrasonic misting system.

\begin{tabular}{lcccc}
\hline Item & Model\# & Quantity & Cost (\$) & Source $^{z}$ \\
\hline Culture system components & & & & \\
$\quad$ Growth chamber & --- & 1 & 75.00 & $1^{\mathrm{y}}$ \\
Media reservoir & --- & 1 & 35.00 & 1 \\
Silicone tubing & --- & 1 & 10.00 & 1 \\
Unidirectional peristaltic pump & UDll1 & 1 & 69.00 & 1 \\
O-rings & --- & 2 & 0.10 & 2 \\
Nylon bolts, nuts, washers & --- & 6 & 0.50 & 2 \\
Polypropylene netting & --- & 1 & 1.00 & 2 \\
Perforated sheet, polypropylene & 46172 & 1 & 1.10 & 3 \\
$\quad$ Rods, Delrin & 42192 & 4 & 0.23 & 3 \\
Electronic items & & & & \\
$\quad$ Ultrasonic humidifier & 66044 & 1 & 50.00 & 4 \\
Time-All AC timer & SB811 & 2 & 15.00 & 2 \\
Liquid level sensor & --- & 1 & 15.00 & 1 \\
Power strip, six-outlet &.-- & 1 & 10.00 & 2 \\
Total & & & 303.22 & \\
\end{tabular}

${ }^{2}$ Sources: 1 = De Novo, San Dimas, Calif; 2 = local hardware store; 3 = United States Plastic Corp., Lima, Ohio; 4 = local drug store.

${ }^{y}$ Culture chambers also can be entirely self-constructed by using Nalgene Bio-Safe carriers (model \#71350001) (Nalgene Co. Rochester, N.Y.) fit with Gelman Bacterial Air Vents (\#4210) (Gelman Sciences, Ann Arbor, Mich.) and 1/8-27 NPT threaded polypropylene couplings (Ark-Plas Products, Inc., Flippin, Alaska). 
culture tray. The culture chamber with attached LLS and misting element, containing the culture tray, silicone tubing, and reservoir, were autoclave together to sterilize.

Following culture-planting on the support tray, the electrical lines were connected, allowing for automatic filling of the culture chamber via the LLS and peristaltic pump. The ultrasonic misting element was then activated. Within 60 see, the entire chamber was filled with a white media cloud. Cultures were misted for 15-rein periods at ten equally spaced times per day.

\section{Construction of an automated culture system}

An automated culture system (ACS) was used that introduced nutrent medium into the culture chamber, bathing the cultures. The medium was then evacuated automatically (De Novo, San Dimas, Calif.) (Tisserat and Vandercook, 1985; 1986; Tisserat, 1990). This system consists of the same components used in the UMS minus the LLS, misting element, culture tray, and power supply. Using the ACS, medium was introduced and evacuated from the culture chamber four equally spaced times per day, and cultures were allowed to soak for 5min periods.

\section{Cultures and media}

Danvers Half Long carrots (Daucus carota L.) (Los Angeles Seed Co., Los Angeles) petioles and leaflets were obtained from sterile, germinated seedlings. To initiate callus, $1-\mathrm{cm}$-long pieces of 3-week-old shootlets consisting of petioles and leaflets were cultured on a basal nutrient medium (BM) contained the following (in $\mathrm{mg} / \mathrm{li}$ ters): $\mathrm{KNO}_{3}, 500 ; \mathrm{Ca}\left(\mathrm{NO}_{3}\right) 23 \mathrm{H}_{2} \mathrm{O}$, $250 ; \mathrm{NH}_{4} \mathrm{~N} \mathrm{O}_{3}, 500 ; \mathrm{H}_{2} \mathrm{~B} \mathrm{O}_{3}, 5.5$; $\mathrm{CaCl}_{2} \quad 2 \mathrm{H}_{2} \mathrm{O}, 70 ; \mathrm{CuSO}_{4} \quad 5 \mathrm{H}_{2} \mathrm{O}, 0.05$; $\mathrm{FeSO}_{4} \quad 7 \mathrm{H}_{2} \mathrm{O}, 2.8 ; \mathrm{MgCl}_{2} \quad 6 \mathrm{H}_{2} \mathrm{O}, 100$;

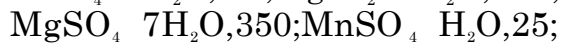
$\mathrm{CoCl}_{2} 6 \mathrm{H}_{2} \mathrm{O}, 0.03$; KI, $1 ; \mathrm{KH}_{2} \mathrm{PO}_{4}$, 150; $\mathrm{Na}_{2} \mathrm{MnO}_{4} 2 \mathrm{H}_{2} \mathrm{O}, 0.28 ; \mathrm{EDTA}$, 40.9; $\mathrm{ZnSO}_{4} 7 \mathrm{H}_{2} \mathrm{O}, 25$; 2,4-dichlorophenoxyacetic acid (2,4-D), 0.1 ; thiamine $\mathrm{HCl}, 0.5$; i-inositol, 120; sucrose, 30,000; and agar, 8000. The $\mathrm{pH}$ value was adjusted to $5.7 \pm 0.1$ with $0.1 \mathrm{~N} \mathrm{HCl}$ or $\mathrm{NaOH}$ before the addition of agar. In some cases, cultures were grown in liquid $\mathrm{BM} \pm 2$,4$\mathrm{D}$ with and without agitation at 25 rpm on a gyrotary shaker. The medium was dispensed in 50-ml aliquots
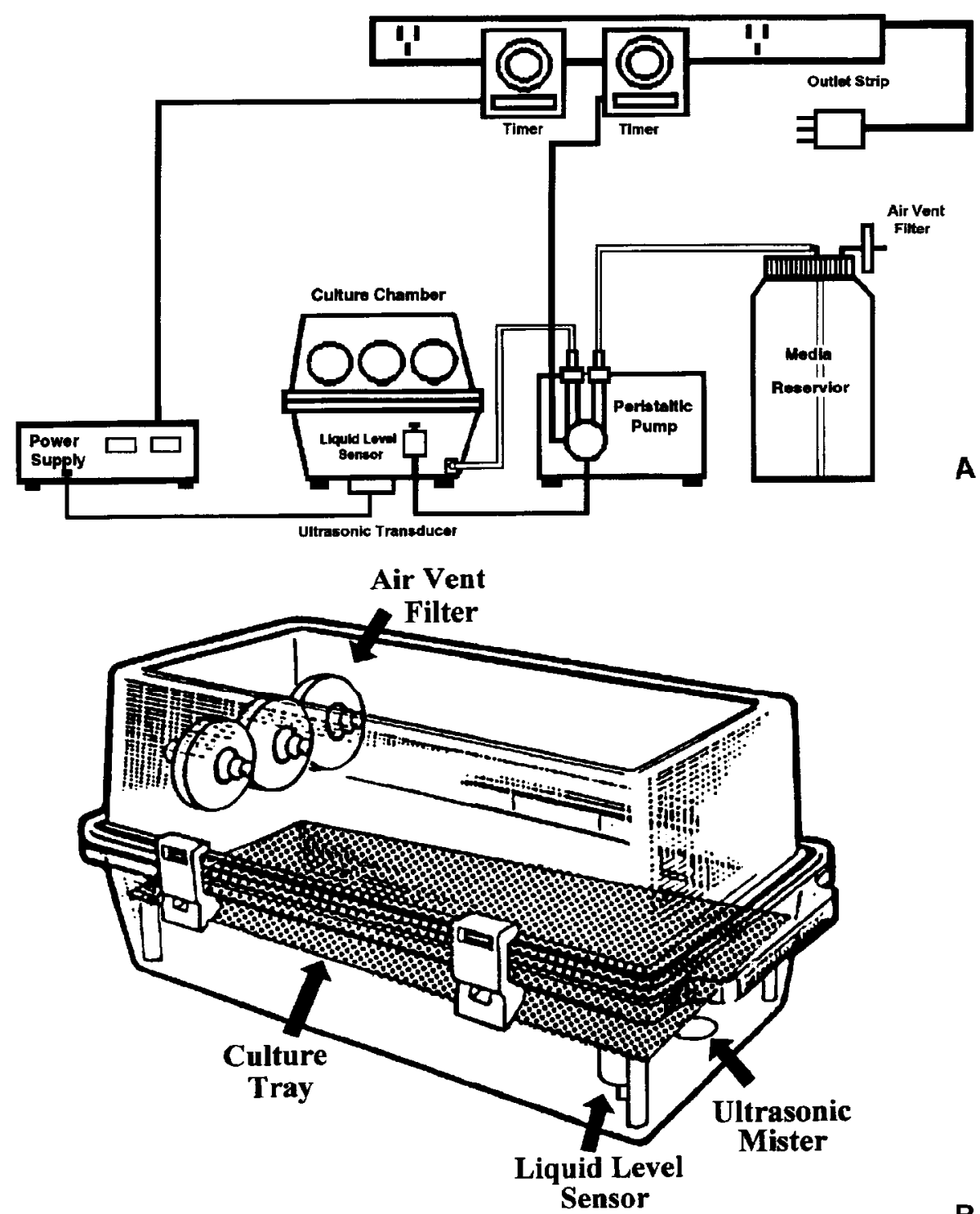

B

Fig. 1. Schematic views of components used in the ultrasonic misting system. (A) Overall view of system. Ultrasonic mist is produced directly in the culture chamber by the misting element. (B) Culture growth chamber used. The perforated culture tray supports the plant tissue cultures above the nutrient medium level, which is monitored by the liquid level sensor. The misting element generates the nutrient mist to provide nutrients for culture growth.

in 275-ml polycarbonate containers and capped with translucent polypropylene lids. When the UMS or the ACS was employed, 1.5-liter BM was sterilized in a 2-liter polycarbonate reservoir bottle. All media were sterilized for 15 min at $1.05 \mathrm{~kg} \mathrm{~cm} \mathrm{~cm}^{-1}$ and 121C. Experiments were conducted with carrots to test the ability of the various culture systems to induce: 1 ) petioles and leaflets to produce embryogenetic callus, and 2) callus to produce asexual embryos and plantlets. A $0.5-\mathrm{cm}^{2}$ piece of embryogenetic carrot callus or three $1-\mathrm{cm}$-long petiole leaf explants obtained from a 3week-old sterile germinated seedling were cultured on BM and BM 2,4-D, respectively, using the: 1) UMS, 2) ACS, 3) agar medium, 4) stationary liquid medium, and 5) shaken liquid medium. Following 4 weeks of incubation, data on morphogenetic responses, including culture fresh weight and number of somatic embryos, were recorded. Nine replicates per treatment were planted, and experiments were repeated at least twice. Cultures were incubated at a constant $26 \pm 1 \mathrm{C}$ under a 16 -hr daily exposure to 2.2 $\mathrm{W} / \mathrm{m}$ cool-white fluorescent lamps.

\section{Growth responses of callus on BM - 2,4-D}

Culturing carrot callus grown on the UMS produced the highest fresh 


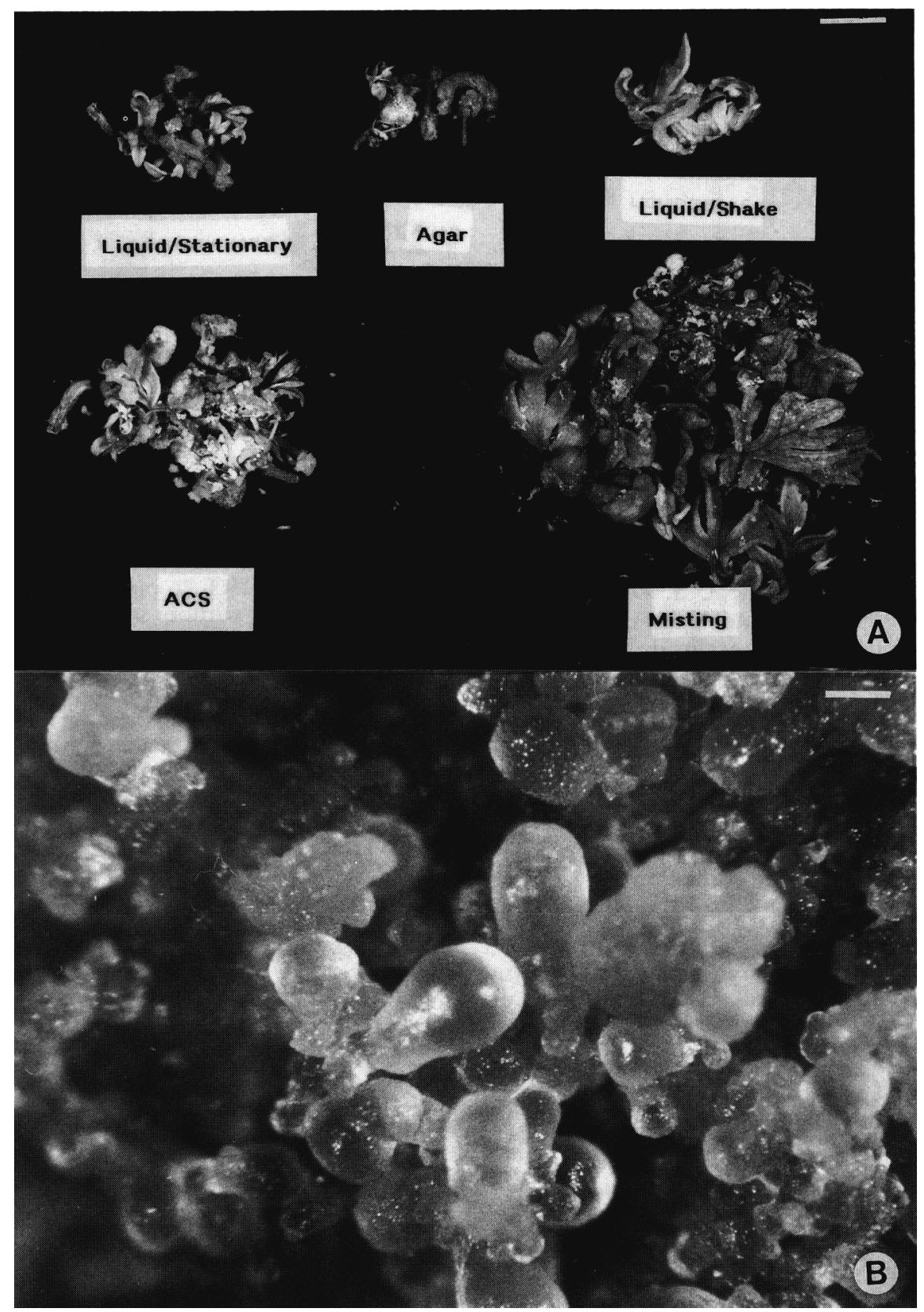

Fig. 2. Examples of culture growth for carrot leaf/petiole culture using the ultrasonic misting system on basal medium. (A) Comparison of carrot callus grown in various culture systems. Note that the greatest growth occurs on the misting system. Bar in upper right corner represents $10 \mathrm{~mm}$. (B) Somatic embryos produced on the surface of carrot leaflets. Note the co-occurrence of minute callus-like clusters, from which somatic embryos are protruding Bar in the upper right corner represents $50 \mu \mathrm{m}$.

weights compared to cultures grown in other treatments (Table 2). Four times as much culture fresh weight was produced in the UMS compared to growth on agar medium. The ACS induced higher fresh weights than all other culture treatments except the UMS (Table 2). Growth in agar and liquid systems was similar. The number of somatic embryos produced in the ACS and agar treatment were sub-

\section{Growth responses of shootlets to BM}

Petiole and leaflet sections enlarged considerably within the first 2 weeks when cultured in the UMS (Fig. $2 \mathrm{~A})$. By the end of 4 weeks, the original cultures had enlarged to as much as five times their original size. A puzzling, unexpected phenomenon that occurred from cultures in the UMS was the direct induction of asexual embryoids from the enlarged leaflet surfaces (Fig. 2A). This phenomenon was not present in other treatments. Callus formation was minimal in the UMS treatments from explants when viewed with the unaided eye compared to that obtained in the agar treatment (Fig. 2A). However, when the UMS cultures were observed with the dissecting microscope at $\times 25$, it was noted that minute callus and/or somatic embryogenetic clusters were produced frequently on the surface of the leaflets. Also, microscopic examination of the surface of leaves and petioles cultured in the UMS suggests that direct somatic embryogenesis without prior callus involvement may be occurring, although this remains to be verified by histological documentation (Fig. 2B). Culture fresh weight was also greatest for the carrot petiole/leaflets cultures in the UMS compared to the other tested systems (Table 1). Fresh weight increases in the UMS were due to the enormous enlargement of the original petiole and leaf tissues and not to callus initiation and proliferation.

\section{Summary}

Weathers and Giles (1988) reported that plant cultures grew as well in an aeroponics bioreactor compared to growth on agar medium with a production cost savings of $65 \%$. Their misting bioreactor (i.e., culture chamber) was constructed of Plexiglas and sterilized by successive rinses of hypochlorite, ethanol, and sterile water. A sterile aerosol spray that bathed the cultures uniformly was produced by a compressed air cylinder and a spray nozzle. Our study supports their findings, except that we obtained even higher yields in our UMS compared to that obtained with the agar system. We demonstrate how a novel technology can be implemented inexpensively to achieve greater growth rates of plant cultures than using the conventional 


\section{TECHNOLOGY AND PRODUCT REPORTS}

Table 2. Morphogenetic responses of carrot Cultures to various culture treatments.

\begin{tabular}{lccc}
\hline Culture condition & Fresh wt $(\mathrm{g})^{z}$ & Difference (\%) $^{y}$ & Embryos/culture $^{z}$ \\
\hline Callus on BM - 2,4-D & & & \\
UMS & $12.06 \pm 2.70 \mathrm{a}$ & 100.0 & $254.2 \pm 58.6 \mathrm{a}$ \\
ACS & $2.79 \pm 0.51 \mathrm{~b}$ & 23.1 & $63.3 \pm 8.3 \mathrm{~b}$ \\
Agar & $2.59 \pm 0.61 \mathrm{~b}$ & 21.5 & $30.0 \pm 2.9 \mathrm{c}$ \\
Liquid, stationary & $0.87 \pm 0.17 \mathrm{c}$ & 7.2 & $0.0 \pm 0.0$ \\
Liquid, shake & $1.04 \pm 0.13 \mathrm{c}$ & 8.6 & $0.0 \pm 0.0$ \\
Petioles/leaflet on BM & & & \\
UMS & $15.57 \pm 0.84 \mathrm{a}$ & 100.0 & $189.4 \pm 13.1$ \\
ACS & $6.33 \pm 0.68 \mathrm{~b}$ & 24.9 & $0.0 \pm 0.0$ \\
Agar & $1.68 \pm 0.12 \mathrm{c}$ & 11.8 & $0.0 \pm 0.0$ \\
Liquid, stationary & $1.49 \pm 0.09 \mathrm{c}$ & 0.0 & $0.0 \pm 0.0$ \\
Liquid, shake & $1.46 \pm 0.09 \mathrm{c}$ & 0.0 & $0.0 \pm 0$ \\
\hline
\end{tabular}

${ }^{2}$ Treatment means sharing the same letter within columns are not significantly different using Student Neuman-Keuls multiple vane test $(\mathrm{P}<0.1)$.

${ }^{Y}$ Comparison of fresh weight of different treatments cultured on the same medium with the ultrasonic treatment.

techniques, vessels, and systems. Aeroponics requires further study to determine the merits of using this unusual system to tissue-culture plants routinely. We devised a simple, unsophisticated UMS that employs an ultrasonic misting element directly in the culture chamber to study this technology, thereby eliminating many components. Our system cost about $\$ 320$ to construct, which compares favorably to the commercial system the Mistifier. It should be noted that it requires about 2 to $3 \mathrm{~h}$ to construct this system. One drawback was found with our UMS: after four to five uses, the misting element usually required replacement due to debris build-up and/or its deterioration. Fortunately, replacements were performed easily. However, for commercial purposes, we recommend that a more heavy-duty ultrasonic misting element be used.

\section{Acknowledgement}

Mention of a trademark name or proprietary product does not constitute a guarantee or warranty of the product by the U.S. Department of Agriculture and does not imply its approval to the exclusion of other products that may be suitable. We thank L.J. Kutz, G.C. Sharma, and P.J. Weathers for critically reading this paper.

\section{Literature Cited}

Fox, J.L. 1988. Plants thrive in ultrasonic nutrient mists. Biotechnology 6:361.

Tisserat, B. and C.E. Vandercook. 1985. Development of an automated plant tissue culture system. Plant Cell and Organ Cult. 5:107-117.

Tisserat, B. and C.E. Vandevcook. 1986. Computerized long-term tissue culture for orchids. Amer. Orchid Soc. Bul. 55: 35 42 .

Tisserat, B. 1990. Micromachines to automate plant tissue culture. Methods Mol. Biol. 6:563-569.

Weathers, P.J. and K.L. Giles. 1988. Regeneration of plants using nutrient mist culture. In Vitro Cell. and Dev. Biol. $24: 121732$. 